\title{
Antibiofilm and antioxidant activities of extracts of crustose coralline alga Lithophyllum sp. from the central Red Sea, Saudi Arabia
}

\author{
Abdulmohsin A. Al-Sofyani \\ Department of Marine Biology, Faculty of Marine Sciences, King Abdul-Aziz University, \\ P. O. Box 80207, Jeddah 21589, Saudi Arabia
}

\begin{abstract}
In this study, the antibiofilm and antioxidant activities of the crustose coralline alga (CCA) Lithophyllum sp. collected from the central Red sea was investigated. The dried CCA samples were extracted with hot water and methanol. Both extracts were tested against marine biofilm forming bacteria to assess the antibiofilm activity. Results showed that methanol extract of the CCA inhibited bacterial growth considerably. The water extract revealed higher antioxidant activity than the methanol extract. The FT-IR spectrum of the CCA showed the presence of functional groups like alkanes, alcohol, carboxylic acid, ethers and esters. In general, results of the present study indicated that CCA produces bioactive compounds, which can inhibit the attachment of unwanted marine bacteria on their surfaces.
\end{abstract}

Keywords: Crustose coralline algae, coral reefs; chemical defence; biofilm; antifouling; Red Sea

\section{Introduction}

Crustose coralline algae (CCA) constitutes an important part in coral reef ecosystems by providing space for the settlement of many organisms including coral species (Webster et al. 2013) and food for herbivores with hardened mouth parts (Steneck, 1997). It has been suggested that CCA makes a substantial contribution to the primary productivity of reef ecosystems due to their abundance (Chisholm, 2003). CCA also act as a cue for the settlement and metamorphosis of the coral larvae. The efficacy of CCA-associated cues in coral larval settlement and metamorphosis has been elucidated by many previous studies (Hayward and Negri, 1999; Kitamura et al. 2007; Tebben et al. 2015). The settlement mediation effects of CCA may be due to the presence of certain compounds (Morse and Morse, 1991) or associated biofilms (Webster et al. 2004). In addition, CCA is reported to release some chemicals that may serve as antifouling 
compounds (Kim et al. 2004; Vermeij et al. 2011).

In the marine environment, both living and non-living surfaces are covered by a microbial layer commonly referred as 'biofilms' (Satheesh et al. 2016). The biofilms associated with marine invertebrates and macroalgae are important for host's defence against the predators or herbivores (Satheesh et al. 2016). Mainly, the microbial communities attached with the marine macroorganisms especially macroalgae are believed to involve in the settlement of invertebrate larval species (Harder et al. 2002; Webster et al. 2004). CCA also provides shelter to a variety of microorganisms and these microbes may play a key role in coral settlement and metamorphosis (Webster et al. 2013).

Most of the marine benthic organisms required to keep their surface free from fouling organisms. Due to this, the organisms express an array of defence strategies starting from mechanical to the production of chemical compounds (Duffy and Hay, 1990; Cronin, 2001; Pansch et al. 2009). There are many previous studies, which reported the settlement-inducing (Pawlik, 1992; Hadfield and Paul, 2001) and inhibiting effects of macroalgal extracts (Walters et al. 2003; Birrell et al. 2008). While CCA is mainly known for its settlement inducing effects on coral larvae (Heyward and Negri, 1999; Raimondi and Morse, 2000; Ritson-Williams et al. 2010; Whalan et al. 2012), their effects against biofilm forming microorganisms is not studied in detail. Hence, in this study, the biofilm inhibiting effects of CCA extracts was assessed under laboratory conditions against biofim forming marine bacterial strain. Results obtained in this study will help us to understand the ecological role of CCA in coral reef ecosystems.

\section{Materials and Methods}

Crustose coralline algal samples (Lithophyllum sp.) were collected from Jeddah coastal waters of the central Red Sea, Saudi Arabia. The samples were kept in sterile polyethene bags with seawater and transported immediately to the laboratory. In the laboratory, algal samples were washed thoroughly with filtered seawater to remove the epibionts. Nearly $3 \mathrm{~mm}$ of CCA top layer was separated by bone cutters and powdered using pestle and mortar for solvent extraction. The CCA samples were dried at room temperature under roof shade. The powdered samples were partitioned into two batches, first batch for solvent extraction and the second for hot aqueous extraction. Briefly, $100 \mathrm{~g}$ powdered CCA sample of dried plant material was extracted with methanol at room temperature. The extract was filtered through Whatman filter paper (no. 54) and dried by rotary vacuum evaporator. For the hot aqueous extraction, $100 \mathrm{~g}$ powdered CCA was extracted in $200 \mathrm{ml}$ of Milli-Q water under $121^{0} \mathrm{C}, 15 \mathrm{psi}$ pressure in an autoclave (Tebben et al., 2015). The crude extract was used for the further assay.

Isolation of biofilm-forming bacteria strain for inhibition assays 
The biofilm-forming bacteria strain used as target organism for this study was isolated from an artificial substratum (aquaculture net) submerged in the Obhur creek of central Red Sea. The biofilm samples isolated from the substratum was serially diluted and cultured using marine agar. Cultivable bacterial colonies were purified and the dominant strain was isolated for identification. The biofilm-forming bacteria strain was identified tentatively based on biochemical properties as Idiomarina sp.

\section{Bacterial growth inhibition assay}

Bacterial growth inhibition assay was conducted using the traditional spectrophotometric method. About $2 \mathrm{ml}$ of overnight bacterial culture $\left(1.8 \times 10^{8}\right.$ cell ml$\left.^{-1}\right)$ was added with $1 \mathrm{~mL}$ of the CCA extracts and incubated for $24 \mathrm{~h}$. Two sets of controls, sample control and assay control were maintained for each extract. The sample control was $2 \mathrm{ml}$ of sterile broth added with 1 $\mathrm{ml}$ of the CCA extracts, whereas the assay control was $2 \mathrm{ml}$ of bacterial culture added with $1 \mathrm{ml}$ of respective solvents used for extraction. The OD (optical density) of the test and control samples was read at $630 \mathrm{~nm}$ in $\mathrm{UV}-\mathrm{V}$ is spectrophotometer at $1 \mathrm{~h}$ interval for 5 $\mathrm{h}$ duration.

\section{Biofilm Inhibition Assay-microtitre plate method}

The biofilm inhibition assay for all the solvent extracts was determined by the 96-well microtiter plate method described by Coffey and Anderson (2014).An overnight culture of biofilm-forming bacteria strain was adjusted to the OD 1.0 at $645 \mathrm{~nm}$. Bacterial culture of 100 and $50 \mu \mathrm{l}$ of the solvent extract were added to the sterile 96-well microtiter plate well and the plate was closed and incubated for $24 \mathrm{~h}$. The controls were maintained without any extract. After incubation, the plate was inverted to remove the planktonic cells and rinsed with sterile water. After that, $150 \mu \mathrm{L}$ of $0.1 \%$ crystal violet was added to each well of the microtiter plate. After $10 \mathrm{~min}$., the plate was inverted to remove crystal violet stain and again rinsed with sterile water to remove the stains. Finally, $150 \mu \mathrm{L}$ of glacial acetic acid was added to each well and kept for $10 \mathrm{~min}$ and after incubation, the plate was read at 630 $\mathrm{nm}$ in a Biotek plate reader.

\section{Total antioxidant activity}

The antioxidant activity of the CCA extracts was assessed by the methods described by Prieto et al. (1999). In brief, the extract $(0.3 \mathrm{ml})$ was mixed with $3 \mathrm{ml}$ of reagent solution, which consists of $4 \mathrm{mM}$ ammonium molybdate, $28 \mathrm{mM}$ sodium phosphate and $0.6 \mathrm{M}$ Sulphuric acid. The extract along with reagent mixture was taken in a test tube and incubated at $95^{\circ} \mathrm{C}$ for $90 \mathrm{~min}$. After incubation, the absorbance was measured using a spectrophotometer at $695 \mathrm{~nm}$. The solvents (methanol and water) were used instead of extracts for blank. A calibration curve was prepared using a different concentration of ascorbic acid and total antioxidant activity was expressed as equal to ascorbic acid.

\section{Results and Discussion}

The methanol and aqueous extracts of the CCA inhibited the bacterial growth that 
was evidenced from the low OD values recorded for the bacterial culture treated with these extracts. Figure 1 explains the growth curve of CCA extracts treated biofilm-forming bacteria strain for a period of $5 \mathrm{~h}$. The OD value was very low for the culture treated with methanol extract. The methanol extract of the CCA showed higher biofilminhibitory activity than aqueous extract in microtitre antibiofilm activity (Fig. 2). The bacterial strain without any treatment (control) showed $440 \%$ biofilm growth during $24 \mathrm{~h}$ period. Bacterial culture treated with aqueous extract exhibited a biofilm growth percentage of 82.27 during this period. However, the methanol extract of the CCA showed negative (-12.18\%) biofilm growth (Fig. 2).

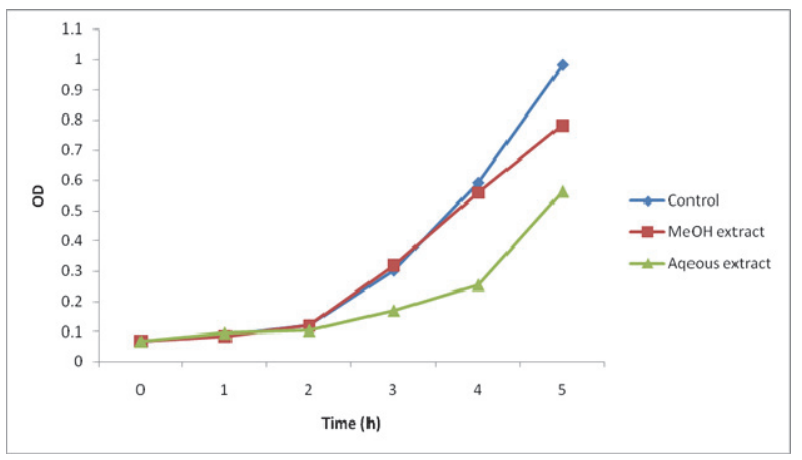

Figure 1. Growth curve of biofilm bacteria treated with CCA extracts for $5 \mathrm{~h}$.

Results of this study revealed that CCA extracts could inhibit the settlement of microorganisms on their surfaces. In the marine environment, space is one of the limiting factors, hence most of the organisms from microbes to invertebrates settle on available surfaces if they found that surface suitable. Microorganisms have a tendency to attach on surfaces and this process on manmade objects submerged in the marine waters attains economical significance. While chemical compounds are mainly used for the control of these biofilms on commercial installations, these chemicals affect the ecosystem health (Satheesh et al., 2016). Natural products from different sources are cited as one of the promising alternatives for antifouling applications and results of this study revealed that bioactive metabolites present in CCA could be used as biofilm inhibitory compounds. Marine algae, in general, possess strong chemical defense against colonizing organisms. The common bioactive metabolites produced by marine macroalgae include polysaccharides, fatty acids, polyphenols and carotenoinds (Perez et al., 2016). CCA are reported to have settlement-inducing compounds, which facilitate the settlement of coral larvae (Tebben et al., 2015). While many researchers studied the antifouling activity of CCA and reported that the activity may be due to physical activities such as sloughing (Steneck and Paine, 1986; Puechel et al., 1996; Boas and Figueiredo, 2004). Results of this study showed that CCA also has settlement inhibiting compounds against colonizing marine bacteria.

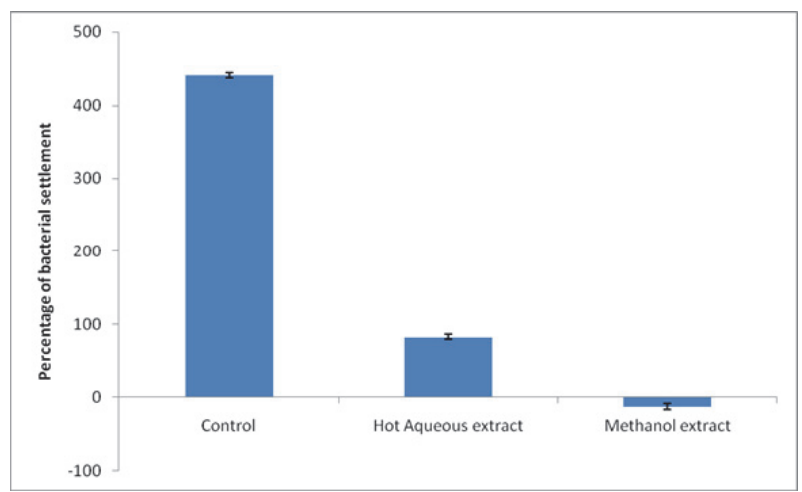


Figure 2. Inhibitory activity of CCA extracts against biofilm-forming bacteria

The water extract of the CCA showed higher antioxidant activity than the methanol extract (Fig. 3). The CCA extracts also showed concentration dependent antioxidant activity. Generally, cells contain a network of antioxidant defense system, which will scavenge the reactive oxygen species (ROS) (Tejada and Sureda, 2014). Many macroalgal species may produce antioxidants as a defense mechanism against epiphytes. For example, the macroalga Caulerpa taxifolia colonized by invasive alga Lophocladia lallemandii produce a higher concentration of antioxidant enzymes and other bioactive compounds (Box Centeno et al., 2008). Alternative and safe antioxidant from plant sources attracted wide interest throughout the world (Aliyu et al., 2013). This is due to the emerging evidence on the protective role of plants and vegetables against cancer and other neurodegenerative diseases (Aliyu et al., 2013). The higher antioxidant activity of the CCA extract, particularly water extract indicated that CCA contains antioxidants, which could be used for biotechnological applications.

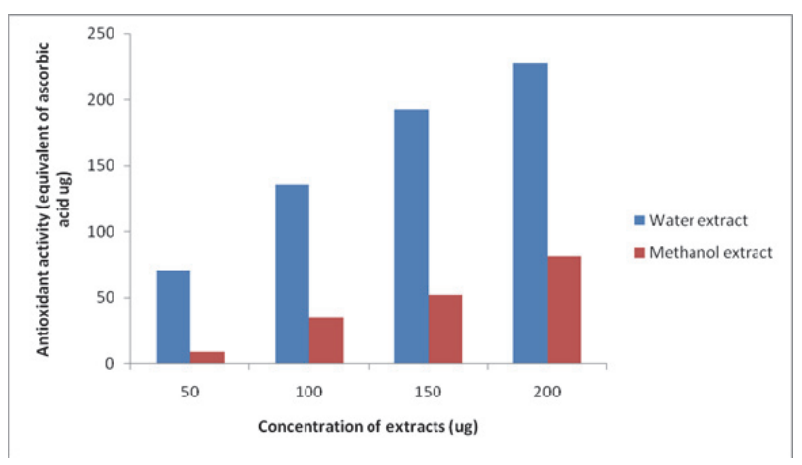

Figure 3. Antioxidant activity of CCA extracts. The antioxidant activity was expressed as equivalent to ascorbic acid.

The FT-IR spectrum of both water and methanol extract of CCA revealed the presence of the functional groups such as alkanes, alcohol, carboxylic acid, ethers and esters. A C-H stretch between 3000-2840, a $\mathrm{CH}_{2}$ bending near at 1460 and a $\mathrm{CH}_{3}$ bending between $1200-1300 \mathrm{~cm}^{-1}$ indicate the presence of alkanes. Whereas a broad $\mathrm{O}-\mathrm{H}$ stretch between 3400-3300 and a C-O stretch between $1260-1000 \mathrm{~cm}^{-1}$ indicate the presence of alcohol. Likewise, an asymmetric C-O-C stretch near 1250 and a symmetric stretch near $1040 \mathrm{~cm}^{-1}$ indicate the presence of aryl alkyl ethers. Similarly, two C-O stretches between $13000-1000 \mathrm{~cm}^{-1}$ indicate the presence of esters. Moreover, A $\mathrm{C}=\mathrm{O}$ between 1730-1700, an $\mathrm{O}-\mathrm{H}$ broad peak near 3400 and a $\mathrm{C}-\mathrm{O}$ stretch between $1320-1210 \mathrm{~cm}^{-1}$ indicates the presence of carboxylic acid (Fig $4 \& 5$ ).

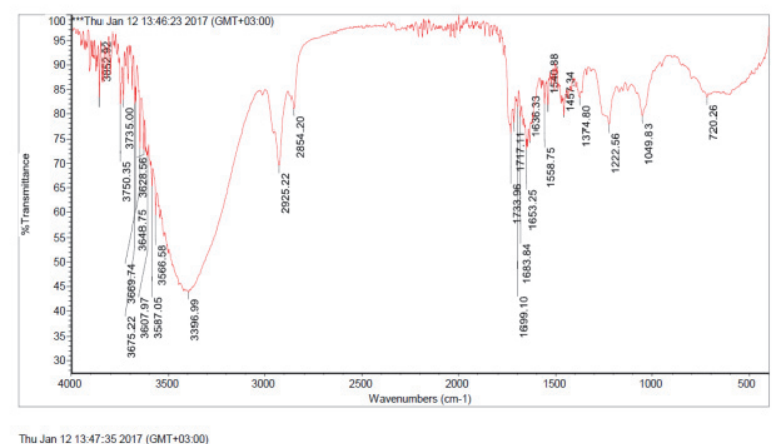




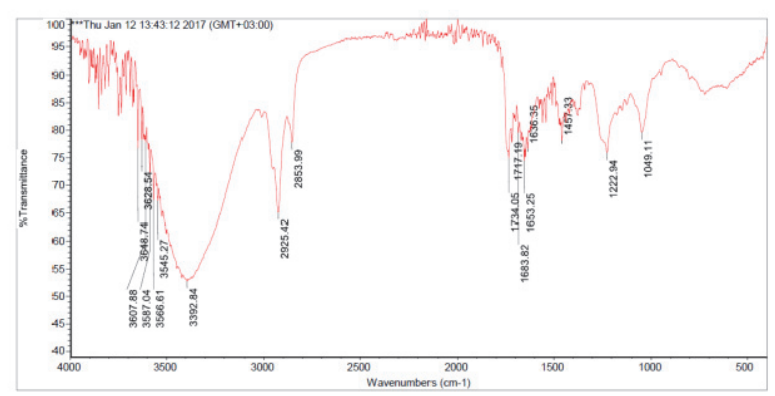

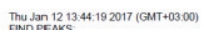

Figure 4. The FT-IR spectrum of methanol extract of crustose coralline alga Lithophyllum sp.

Figure 5. The FT-IR spectrum of water extract of crustose coralline alga Lithophyllum sp.

It has been reported that a variety of chemical compounds, which can act against epiphytes/pathogens, are produced by CCA (Kim et al. 2004, Luyen et al. 2009). Therefore, further purification and characterization process could reveal the nature of the compound, which is responsible for bioactivity. Also, the FT-IR result revealed that there areee not many cha+nges in between the spectrum of water and methanol extracts, which may be due to the fact that both water and methanol are polar solvents. Because the solubility of the compounds is depends on the polarity of the solvents used for extraction (Turkmen et al., 2006; Dai and Mumper, 2010). Therefore, by using on and mid-polar solvents some other novel compounds could also be extracted from CCA. However, considering the results of the antioxidant and antibiofilm activities it is concluded that the CCA produce the compounds, which can inhibit the attachment of unwanted marine bacteria on their surfaces. Similar antisettlement effects against other invertebrates will be a topic of interest for further studies.

\section{References}

Aliyu, A.B., Ibrahim, M.A., Musa, A,M., Musa, A.O., Kiplimo, J.J. and Oyewale, A.O. (2013). Free radical scavenging and total antioxidant capacity of root extracts of Anchomanes difformis Engl. (Araceae). Acta Poloniae Pharmaceutica , 70 :115-121.

Birrell, C.L., McCook, L.J., Willis, B.L. and Diaz-Pulido, G. (2008). Effects of benthic algae on the replenishment of corals and the implications for the resilience of coral reefs. Oceanography and Marine Biology - An Annual Review 46:25-64

Bôas, A. B.V. and Figueiredo, M.A.deO. (2004). Are antifouling effects in coralline algae species specific? Brazilian Journal of Oceanography, 52(1):11-18

Box Centeno, A., Sureda, A., Terrados, J., Pons, A. and Deudero, S. (2008) Antioxidant response and caulerpenyne production of the alien Caulerpa taxifolia (Vahl) epiphytized by the invasive algae Lophocladia lallemandii (Montagne). Journal of Experimental Marine Biol ogy and Ecology 364: 24-28

Chisholm, J.R.M. (2003) Primary productivity of reefbuilding crustose coralline algae. Limnology and Oceanography 48: 1376-1387

Coffey , B.M. and Anderson, G.G. (2014) Biofilm formation in the 96-well microtiter plate. Methods in Molecular Biology. 1149:631-41. doi: 10.1007/978-14939-0473-0_48.

Cronin, G. (2001) Resource allocation in seaweed and marine invertebrates: chemical defense patterns in relation to defense theories. In: McClintock. J.B. and Baker, B.J. (eds) Marine chemical ecology. CRC Press, Boca Raton, FL, p 325-353

Dai, J., Mumper, R.J. (2010) Plant phenolics: extraction, analysis and their antioxidant and anticancer properties. Molecules. 15:7313e52.

Duffy, J.E. and Hay, M.E. (1990) Seaweed adaptation to herbivory. Bioscience 40:368-375 
Hadfield, M.G. and Paul, V.J. (2001) Natural chemical cues for settlement and metamorphosis of marine-invertebrate larvae. In: McClintock, J.B. and Baker, B.J. (eds) Marine chemical ecology. CRC Press, Boca Raton, FL, p 431-462

Harder, T., Lau, S.C.K., Dahms, H.U. and Qian, P.Y. (2002) Isolation of bacterial metabolites as natural inducers for larval settlement in the marine polychaete Hydroides elegans (Haswell). Journal of Chemical Ecology 28:2029-2044

Heyward ,A.J. and Negri ,A.P. (1999). Natural inducers for coral larval metamorphosis. Coral Reefs 18: 273-279

Kim, M.J., Choi, J.C., Kang, S.E., Cho, J.Y., Jin, H.J., Chun, B.S. and Hong, Y.K. (2004) Multiple allelopathic activity of the crustose coralline alga Lithophyllum yessoense against settlement and germination of seaweed spores. Journal of Applied Phycology 16: 175-179

Kitamura, M., Koyama, T., Nakano, Y. and Uemura, D. (2007) Characterization of a natural inducer of coral larval metamorphosis. Journal of Experimental Marine Biology and Ecology 340: 96-102.

Luyen, Q. H., Cho, J. Y., Choi, J. S., Kang, J. Y., Park, N. G. and Hong, Y. K. (2009) Isolation of algal spore lytic C17 fatty acid from the crustose coralline seaweed Lithophyllum yessoense. Journal of Applied Phycology 21:423-7.

Morse, D. E. and Morse, A. (1991) Enzymatic characterization of the morphogen recognized by Agaricia humilis (Scleractinian coral) larvae. Biological Bulletin 181:104-122.

Pansch, C., Cerda, O., Lenz, M., Wahl, M., and Martin Thiel, M. (2009) Consequences of light reduction for antiherbivore defense and bioactivity against mussels in four seaweed species from northern-central Chile. Marine Ecology Progress Series, 381: 83-97, doi: 10.3354/meps07943

Pawlik, J.R. (1992) Chemical ecology of the settlement of benthic marine invertebrates. Oceanography and Marine Biology - An Annual Review. 30:273-335

Pérez, M.J., Falqué, E. and Domínguez, H. (2016) Antimicrobial Action of Compounds from Marine Seaweed. Marine Drugs, 14, 52; doi:10.3390/md14030052

Prieto P., Pineda M. and Anguilar M. (1999) Spectrophotometric quantitation of antioxidant capacity through the formation of a phosphomolybdenum complex: specific application to the determination of vitamin E. Analytical Biochemistry 269: 337-341.

Pueschel, C. M., Miller, T. J. and McCausland, B. B. (1996) Development of epithallial cells in Corallina officinalis and Lithophyllum impressum (Corallinales, Rhodophyta). Phycologia, 35:161-169

Raimondi, P.T. and Morse, A.N.C. (2000) The consequences of complex behaviour in a coral. Ecology 81: 3193-3211.

Ritson-Williams, R., Paul, V.J., Arnold, S.N. and Steneck, R.S. (2010) Larval settlement preferences and postsettlement survival of the threatened Caribbean corals Acropora palmate and A. cervicornis. Coral Reefs 29: 7181.

Satheesh, S., Ba-akdah, M.A. and Al-Sofyani, A.A. (2016) Natural antifouling compound production by microbes associated with marine macroorganisms-A review. Electronic Journal of Biotechnology, 21:26-35

Steneck, R. S. (1997) Crustose corallines, other algal functional groups, herbivores and sediments: Complex interactions along reef productivity gradients. In : Proceedings of the 8th International Coral Reef Symposium, v. 1, p. 23-28.

Steneck, R. S. and Paine, R. T. (1986). Ecological and taxonomic studies of shallow-water encrusting Corallinaceae (Rhodophyta) of the northerly northeastern Pacific. Phycologia, 25:221-240.

Tebben, J., Motti, C. A., Siboni, N., Tapiolas, D.M., Negri, A.P., Schupp, P.J., Kitamura, M., Hatta, M., P. D. Steinberg, P.D. and Harder, T. (2015) Chemical mediation of coral larval settlement by crustose coralline algae. Scientific Reports 5, 10803; doi: 10.1038/srep10803

Tejada, S. and Sureda, A. (2014). Antioxidant response of the brown algae Dictyota dichotoma epiphytized by the invasive red macroalgae Lophocladia lallemandii. Journal of Coastal Life Medicine 2: 362-366

Turkmen, N., Sari, F. and Velioglu, Y.S. (2006) Effects of extraction solvents on concentration and antioxidant activity of black and black mate tea polyphenols determined by ferrous tartrate and Foline Ciocalteu methods. Food Chemistry 99:835e41.

Vermeij, M. J. A. , Dailer, M. L. and Smith, C. M. (2011) Crustose coralline algae can suppress macroalgal growth and recruitment on Hawaiian coral reefs. Marine Ecology Progress Series 422: 1-7. doi: 10.3354/meps08964 
Walters, L.J., Smith, C.M. and Hadfield, M.G. (2003) Recruitment of sessile marine invertebrates on Hawaiian macrophytes: Do pre-settlement or post-settlement processes keep plants free from fouling? Bulletin of Marine Science 72:813-839

Webster, N.S., Smith, L.D., Heyward, A.J., Watts, J.E.M., Webb, R.I., Blackall, L.L. and Negri, A.P. (2004) Metamorphosis of a scleractinian coral in response to microbial biofilms. Applied and Environmental Microbiology 70:1213-1221
Webster, N.S., Uthicke, S., Botte, E.S. Flores, F. and Negri, A.P. (2013) Ocean acidification reduces induction of coral settlement by crustose coralline algae. Global Change Biology 19, 303-315, doi: 10.1111/gcb.12008

Whalan, S., Webster, N.S. and Negri, A.P. (2012) Crustose Coralline Algae and a Cnidarian Neuropeptide Trigger Larval Settlement in Two Coral Reef Sponges. PLoS ONE 7(1): e30386. doi:10.1371/journal.pone.0030386 


\section{الأغشية والأنشطة المضادة للأكسدة المستخلصة من الطحالب الحمراء الكلسية لجنس ليثوفيلوم Lithophyllum sp.}

\section{عبدالمحسن السفياني}

قسم الأحياء البحرية ، كلية علوم البحار - جامعة الملك عبالعزيز

ص r

المملكة العربية السعودية

المستخلص: في هذه الدراسة تم التحقق من الأغشية المضادة والأنشطة المضادة للأكسدة للطحالب الحمراء الكلسية من جنس . Lithophyllum sp. sp التي تم جمعها من وسط البحر الأحمر • حيث تم استخلاص عينات الطحالب الحمراء الكلسية المجففه بالماء الساخن والميثانول. ثم تم اختبار كلا المستخلصين الناتجة بالطريقتين السابقتين ضد تكون الأغشية الحيوية البحرية البكتيرية لتقييم أنشطتها المضادة ـ أظهرت النتائج أن مستخلص الميثانول من الطحالب الحمراء الكلسية يحبط نمو البكتيريا إلى في إنى حد كبير ، بينما أظهرت عمليات الاستخلاص بالماء أن لها نشاط مضاد للأكسدة أعلى من مستخلص الميثانول. أظهر جهاز طيف الأشعة تحت الحمراء (FT-IR) أن التركيب الطيفي لمستخلص الطحالب الحمراء المتكلسة وجود مجموعات فعالة مثل من فئل فئل الأكانات، الكحول، حامض الكربوكسيلك، الاثيرات والاسترات. عموما أشارت نتائج الدراسة الحالية إلى أن الطحالب الحمراء الكلسية تتتج مركبات حيوية نشطة التي يمكن أن تمنع التصاق البكتيريا البحرية الغير مرغوب فيها على أسطحها.

الكلمات المفتاحية : الطحالب الحمراء الكلسية ،الشعاب المرجانية ،الدفاع الكيميائي ، الأغشية حيوية ،الأغشية ألمضادة ، البحر الاحمر • 